\title{
MicroRNA-129-5p promotes proliferation and metastasis of hepatocellular carcinoma by regulating the BMP2 gene
}

\author{
ZENGYAO LIU ${ }^{1}$, JIEFEI SUN ${ }^{2}$, XIAOCHUN WANG ${ }^{3}$ and ZHENYUAN CAO ${ }^{4}$ \\ ${ }^{1}$ Department of Intervention, The First Affiliated Hospital of Harbin Medical University, Harbin, Heilongjiang 150001; \\ ${ }^{2}$ Interventional Catheter Therapy Section Office, Zhaodong Renmin Hospital, Zhaodong, Heilongjiang 151100; \\ Departments of ${ }^{3}$ Nursing and ${ }^{4}$ Intervention, The First Affiliated Hospital of Harbin \\ Medical University, Harbin, Heilongjiang 150001, P.R. China
}

Received November 11, 2019; Accepted November 26, 2020

DOI: $10.3892 / \mathrm{etm} .2021 .9688$

\begin{abstract}
Hepatocellular carcinoma (HCC) is a malignant tumor that poses a serious threat to human health. Due to its occult onset and rapid development, $\mathrm{HCC}$ is a challenge to diagnose early and effectively treat, and thus patients with HCC often have an unfavorable prognosis. MicroRNA (miR)-129 and its target gene play an important role in the regulation of various diseases. Therefore, the aim of the present study was to investigate the role and mechanism of action for miR-129-5p in the development of HCC. Quantitative results of clinical samples analyzed using reverse transcription-quantitative PCR suggested that miR-129-5p had a significantly lower expression level in tumoral tissues compared with corresponding peritumoral tissues. Overexpression of miR-129-5p in HCC cells was performed using a transfection technique, followed by MTT, Transwell, invasion and wound healing assays to detect the effect of miR-129-5p on the cell cytotoxicity and metastasis of liver cancer in vitro. The downstream target gene of miR-129-5p, bone morphogenetic protein 2 (BMP2), was determined using a luciferase reporter assay. Overexpression of miR-129-5p played a vital role in decreasing cytotoxicity and promoting metastasis of $\mathrm{HCC}$, which may be attributed to its inhibitory effect on the expression of its target gene, BMP2. In clinical samples, miR-129-5p expression levels were found to be negatively correlated with BMP2 and closely associated with HCC metastasis and infiltration. Collectively, the results suggested that miR-129-5p may contribute to proliferation and metastasis of HCC through its target gene, BMP2, and thus may be a potential novel therapeutic target for the treatment of HCC.
\end{abstract}

Correspondence to: Dr Zhenyuan Cao, Department of Intervention, The First Affiliated Hospital of Harbin Medical University, 23 Youzheng Street, Harbin, Heilongjiang 150001, P.R. China

E-mail: caozhengyuan20@hotmail.com

Key words: hepatocellular carcinoma, microRNA-129-5p, bone morphogenetic protein 2, proliferation, metastasis

\section{Introduction}

Hepatocellular carcinoma (HCC) is a primary liver cancer that is derived from hepatocytes, accounting for $95 \%$ of all types of primary liver cancer (1). HCC is a malignant tumor that seriously threatens human health, with an incidence and mortality among the highest of all tumor types (2). The potential risk factors for HCC include viral infections, cirrhosis, aflatoxina and alcoholism, which are speculated to lead to fundamental genetic mutations, causing oncogene activation and tumor suppressor gene inactivation (3). An oncogene is a dominant gene that can cause malignant transformation of cells after its mutation, while a tumor suppressor gene is a recessive gene that may lead to the transformation of normal cells into cancerous cells due to disruption of the regulation of associated cell division and proliferation when the tumor suppressor is mutated or lost (4). In the development of several tumors, the loss of tumor suppressor genes may be more important than the activation of an oncogene since the former exerts resistance and protection at various stages of tumor development, including regulation of the cell cycle, inhibition of cell adhesion and migration, suppression of proliferation of cells with DNA damage and repair of damaged DNA $(5,6)$. The underlying mechanism of action behind liver cancer has been investigated in recent years and several tumor-related genes have been identified; however, the exact molecular mechanism of action is yet to be elucidated (7-13).

MicroRNAs (miRNAs/miRs) are non-coding singlestranded small RNAs that consist of 22 nucleotides (14). miRNAs, which are widely found in plants, animals and human cells, exhibit a post-transcriptional regulatory effect by degrading mRNA or inhibiting translation of mRNA by binding to the 3' untranslated region (3'UTR) of their target gene mRNA (15). Previous studies have shown that miRNAs play an important regulatory role in cell proliferation, apoptosis, insulin secretion and neurodevelopment; miRNAs are also essential to the late stage of embryonic development $(16,17)$. It has also been reported that miR-196 is involved in the regulation of mammalian limb development (5) and that miR-181 plays a role in the regulation of mammalian blood cell differentiation (18). In mammals, miR-375 exhibits a regulatory effect on insulin secretion (6). In addition, the development 
of nervous systems of some species, such as nematodes and zebrafish, is also regulated by lin-4, miR-142, miR-15, miR-16 and let-7 miRNAs (19). miRNAs are widely used for the diagnosis and prognosis of various diseases and also serve as tumor markers for candidate cancer types $(6,20,21)$. Previous studies have shown that abnormal expression of miRNAs in tumors can lead to oncogene activation and tumor suppressor gene dysregulation, which may ultimately contribute to tumor progression (22-24). The dysregulated expression of miRNAs may function as an important regulator to liver failure. The development of HCC is often accompanied with the dysregulation of miRNAs. A number of miRNAs have been associated with the clinicopathological features of liver cancer (25-27). miR-320, miR-486, miR-705 and miR-1224 were shown to be increased, whilst the expression of miR-27B, miR-214, miR-199-3p, miR-182 and miR-183, were shown to be decreased in hepatocellular carcinoma tissues (27). It has been previously demonstrated that miRNAs serve an important role in the progression of HCC, potentially promoting the proliferation of tumor cells, inhibiting tumor cell apoptosis and facilitating metastasis by directly targeting their corresponding mRNAs (28-34).

miR-129-5p regulates the development and progression of various tumors by regulating the cell cycle, proliferation, apoptosis, migration, invasion and angiogenesis, as well as other physiological and pathological processes (25). In neuroblastomas, miR-129 inhibits tumor growth by targeting Myosin X (MYO10) (35). Furthermore, miR-129-5p promotes cell proliferation and invasion; and inhibits apoptosis through regulating the SOX4 pathway in renal cell carcinoma (26). A previous study has reported that miR-129-5p is an important biomarker for single ventricle heart failure (36). In addition, the expression of miR-129 may be an independent prognostic marker for biochemical recurrence (BCR)-free survival in patients with prostate cancer and the overexpression of miR-129 significantly attenuates prostate cancer cell proliferation by regulating cell cycle-regulated protein expression levels (27). To the best of our knowledge, no studies exist that have investigated the correlation between miR-129-5p and HCC. Therefore, the present study was conducted to investigate the effect of miR-129-5p on the proliferative and invasive capabilities of HCC cells.

\section{Materials and methods}

Clinical tissue specimens. All 45 patients with HCC involved in the present study were enrolled from The First Affiliated Hospital of Harbin Medical University (Harbin, China), after signing informed consent forms from May 2015 to Sep 2017. Fresh tumor and peritumoral tissue were frozen in liquid nitrogen immediately after dissection during the surgery. None of the patients in the present study received any other preoperative adjuvant therapy before surgery. The clinical characteristics of patients with liver cancer are presented in Table I. Among the 45 patients, there were 29 males and 16 females were 16 . All 45 patients were clinically diagnosed with HCC. Patients with intrahepatic metastasis, vascular invasion, or capsular invasion as found by Computer Tomography and pathological examination were used to classify metastatic/invasion samples. The age ranged from 27 to 71 years, of which 20 patients were $\geq 55$ years old and 25 patients $<55$ years old. There were 29 patients with intrahepatic metastases, vascular invasion or capsular invasion (metastatic/invasion samples, 64.4\%). There were 16 patients with metastatic/invasion. The present study was approved by the Institutional Ethics Committee of Harbin Medical University (approval no. KY2017059; Harbin, China).

Cell culture. The cell strain and human liver cancer cell lines (HepG2 and Huh7) were provided by the China Center for Type Culture Collection. Cells were seeded in DMEM (HyClone, GE Healthcare Life Sciences), supplemented with $10 \%$ FBS (HyClone, GE Healthcare Life Sciences), $100 \mathrm{U} / \mathrm{ml}$ penicillin and $100 \mu \mathrm{g} / \mathrm{ml}$ streptomycin at $\mathrm{pH}$ 7.2-7.4 and then cultured routinely in an incubator $\left(37^{\circ} \mathrm{C}, 5 \% \mathrm{CO}_{2}, 95 \%\right.$ air with saturated humidity).

miRNA and transfection. Transfections were performed using miRNAs analogs, miR-129-5p mimics (5'-CUUUUU GCGGUCUGGGCUUGC-3'), miR-129-5p inhibitor (5'-GCA AGCCCAGACCGCAAAAAGUU-3'), negative control (NC; 5'-UUCUCCGAACGUGUCACGUTT-3') and inhibitor NC (5'-CAGUACUUUUGUGUAGUACAA-3'), which were synthesized by Shanghai GenePharma Co., Ltd.. The NC was a synthetic scrambled double oligonucleotide that do not target any mRNA. The transfection reagent was Lipofectamine ${ }^{\circledR} 2000$ (cat. no. 11668-027; Invitrogen; Thermo Fisher Scientific, Inc.) and the operating procedures were performed following the manufacturer's protocols. The cells were cultured for 24 and $48 \mathrm{~h}$ at $37^{\circ} \mathrm{C}$ and $5 \% \mathrm{CO}_{2}$ for subsequent experiments.

Reverse transcription-quantitative PCR (RT-qPCR). The reverse transcription of miRNA was carried out as described previously (37). Total RNA from tissue specimens, HepG2 cells or Huh7 cells was isolated using TRIzol ${ }^{\circledR}$ reagent (Invitrogen; Thermo Fisher Scientific, Inc.) following manufacturer's protocols. Subsequently, the RNA was converted into cDNA using High-Capacity cDNA Reverse Transcription kit (cat. no. 4368814; ABI; Thermo Fisher Scientific, Inc.). The temperature of reverse transcription is set as follows: $25^{\circ} \mathrm{C}$ for $10 \mathrm{~min}, 37^{\circ} \mathrm{C}$ for $120 \mathrm{~min}, 85^{\circ} \mathrm{C}$ for $5 \mathrm{~min}$ and $4^{\circ} \mathrm{C}$ for $5 \mathrm{~min}$.

miRNA expression levels were quantitatively determined using the Fast SYBR ${ }^{\mathrm{TM}}$ Green PCR Master Mix kit (cat. no. 4385610; ABI; Thermo Fisher Scientific, Inc.), with U6 snRNA as an internal reference for miRNA. Primers were used for miRNA detection as follows: miR-129-5p forward, 5'-CTT TTTGCGGTCTGGGCTTGC-3' and reverse, 5'-GTGCAG GGTCCGAGGT-3' and U6 snRNA forward, 5'-TGCGGGTGC TCGCTTCGGCAGC-3' and reverse, 5'-GTGCAGGGTCCG AGGT-3'. Primers were used for mRNA detection as follows: Bone morphogenetic protein 2 (BMP2) forward, 5'-AAGTCT CCTCCTTCATCAGTATACGCTCG-3' and reverse, 5'-GAT ATCGAATTCGATATCAAGCTGAT- $3^{\prime}$ and $\beta$-actin forward, 5'-TACCTCATGAAGATCCTCACC-3' and reverse, 5'-TTT CGTGGATGCCACAGGAC- 3 '. The $\beta$-actin mRNA level was used for normalization. All primers were obtained from Invitrogen (Shanghai, China). The annealing temperature for BMP2 and miR-129-5p was $60^{\circ} \mathrm{C}$. The full thermocycling conditions for qPCR are as follows: Initial denaturation at $95^{\circ} \mathrm{C}$ for $2 \mathrm{~min}$, followed by 40 cycles of $95^{\circ} \mathrm{C}$ for $30 \mathrm{sec}$ and $60^{\circ} \mathrm{C}$ for $1 \mathrm{~min}$. The method of $\Delta \Delta \mathrm{Cq}$ was used to determine 
Table I. Clinical features of the patients with hepatocellular carcinomas.

\begin{tabular}{|c|c|c|c|c|c|c|}
\hline Patient no. & Age (year) & Gender & $\begin{array}{c}\text { Tumor size } \\
(\mathrm{cm} \times \mathrm{cm} \times \mathrm{cm})\end{array}$ & $\begin{array}{l}\text { Intrahepatic } \\
\text { metastases }\end{array}$ & $\begin{array}{l}\text { Vascular } \\
\text { invasion }\end{array}$ & $\begin{array}{l}\text { Capsular } \\
\text { invasion }\end{array}$ \\
\hline 1 & 59 & M & $3 \times 3 \times 2$ & - & - & - \\
\hline 2 & 61 & M & $4 \times 4 \times 2$ & - & - & - \\
\hline 3 & 52 & $\mathrm{~F}$ & $5 \times 3 \times 3$ & - & - & - \\
\hline 4 & 50 & M & $9 \times 7 \times 3$ & - & - & - \\
\hline 5 & 46 & M & $10 \times 7.5 \times 5$ & + & + & + \\
\hline 6 & 38 & M & $3 \times 2 \times 2$ & - & - & - \\
\hline 7 & 70 & M & $6 \times 4 \times 2$ & - & - & + \\
\hline 8 & 71 & $\mathrm{~F}$ & $7 \times 5 \times 3$ & + & + & + \\
\hline 9 & 51 & $\mathrm{M}$ & $19 \times 12 \times 7$ & + & - & + \\
\hline 10 & 62 & $\mathrm{~F}$ & $12 \times 11.5 \times 10$ & + & - & + \\
\hline 11 & 50 & $\mathrm{~F}$ & $6.5 \times 6 \times 5.5$ & - & + & - \\
\hline 12 & 57 & $\mathrm{~F}$ & $9 \times 8 \times 7.5$ & - & + & - \\
\hline 13 & 43 & M & $4 \times 3 \times 2.5$ & + & - & - \\
\hline 14 & 70 & M & $5.5 \times 5.5 \times 3$ & - & + & + \\
\hline 15 & 60 & M & $18 \times 15 \times 7$ & - & - & - \\
\hline 16 & 66 & M & $12 \times 9 \times 6.5$ & + & + & + \\
\hline 17 & 67 & M & $4 \times 3 \times 2.5$ & - & - & - \\
\hline 18 & 60 & $\mathrm{M}$ & $5.5 \times 4 \times 4$ & + & - & + \\
\hline 19 & 49 & M & $10 \times 8.5 \times 5$ & - & - & - \\
\hline 20 & 47 & $\mathrm{M}$ & $6.5 \times 6 \times 3$ & - & - & - \\
\hline 21 & 68 & $\mathrm{M}$ & $17 \times 12 \times 6$ & - & - & + \\
\hline 22 & 52 & $\mathrm{~F}$ & $12 \times 10 \times 8$ & - & - & - \\
\hline 23 & 39 & $\mathrm{M}$ & $4 \times 3 \times 3$ & - & - & - \\
\hline 24 & 42 & M & $7 \times 5 \times 3.5$ & - & - & + \\
\hline 25 & 60 & $\mathrm{~F}$ & $9 \times 7 \times 4.5$ & + & - & - \\
\hline 26 & 53 & $\mathrm{~F}$ & $14 \times 9 \times 8$ & - & + & - \\
\hline 27 & 50 & $\mathrm{~F}$ & $10 \times 7 \times 6.5$ & - & - & - \\
\hline 28 & 27 & $\mathrm{M}$ & $9.5 \times 8 \times 7.5$ & - & - & - \\
\hline 29 & 46 & $\mathrm{M}$ & $4 \times 3.5 \times 3$ & - & - & - \\
\hline 30 & 52 & $\mathrm{~F}$ & $8 \times 6 \times 5.5$ & - & - & - \\
\hline 31 & 58 & $\mathrm{M}$ & $6 \times 4 \times 4$ & - & - & - \\
\hline 32 & 46 & $\mathrm{M}$ & $9 \times 6.5 \times 5$ & - & - & - \\
\hline 33 & 37 & $\mathrm{~F}$ & $7 \times 2 \times 2$ & - & - & + \\
\hline 34 & 54 & $\mathrm{M}$ & $3 \times 2.7 \times 2$ & - & + & + \\
\hline 35 & 43 & $\mathrm{M}$ & $4.5 \times 1.5 \times 1$ & + & - & - \\
\hline 36 & 69 & $\mathrm{~F}$ & $4.5 \times 3 \times 3$ & - & + & - \\
\hline 37 & 57 & M & $6 \times 5.5 \times 4.5$ & - & + & - \\
\hline 38 & 46 & M & $4 \times 4 \times 1.5$ & - & - & + \\
\hline 39 & 50 & $\mathrm{M}$ & $7 \times 3.5 \times 2.5$ & - & - & + \\
\hline 40 & 67 & $\mathrm{~F}$ & $8 \times 6.5 \times 4$ & - & + & - \\
\hline 41 & 70 & $\mathrm{M}$ & $6 \times 3.5 \times 3$ & + & + & + \\
\hline 42 & 55 & $\mathrm{~F}$ & $4 \times 2 \times 2$ & + & - & - \\
\hline 43 & 43 & $\mathrm{~F}$ & $5 \times 4.5 \times 2$ & + & + & + \\
\hline 44 & 54 & $\mathrm{~F}$ & $3 \times 2 \times 2$ & + & - & + \\
\hline 45 & 62 & $\mathrm{M}$ & $4 \times 3.5 \times 3$ & - & + & - \\
\hline
\end{tabular}

F, female; M, male; +, positive; -, negative.

the relative quantity of mRNA expression in samples, and fold change was determined as $2^{-\Delta \Delta \mathrm{Cq}}(38)$.
Western blotting. Cells were lysed using modified cell lysate RIPA buffer (50 nM Tris $\mathrm{HCl}, \mathrm{pH} 7.4,150 \mathrm{mM} \mathrm{NaCl}$, 
$1 \%$ NP-40, $0.25 \%$ sodium deoxycholate and $0.5 \%$ SDS) to extract proteins. Protein concentration was determined using a bicinchoninic acid protein assay kit. In total, $80 \mu \mathrm{g}$ protein was loaded into each well. After being separated by $12 \%$ SDS-PAGE, the protein was transferred onto a PVDF membrane. The membranes were blocked in $1 \%$ BSA (Gibco; Thermo Fisher Scientific, Inc.) with $0.05 \%$ Tween-20 at $37^{\circ} \mathrm{C}$ for $1 \mathrm{~h}$. The membranes were then incubated with rabbit monoclonal anti-BMP2 (cat. no. ab214821; 1:1,000; Abcam) and goat monoclonal anti- $\beta$-actin (cat. no. sc-8432; 1:2,000; Santa Cruz Biotechnology, Inc.) at $4^{\circ} \mathrm{C}$ overnight. After incubation with the horseradish peroxidase-conjugated goat anti-rabbit IgG secondary antibody (cat. no. ab205718; 1:20,000) and rabbit anti-goat IgG (cat. no. ab6741; 1:2,000) at room temperature for $1 \mathrm{~h}$, the signal was detected by using Clarity Max $^{\mathrm{TM}}$ Western ECL Substrate (Bio-Rad Laboratories, Inc.). Tanon 1000 digital image gel analytical system (Tanon Science \& Technology Co., Ltd.) was used for photography and quantification.

Bioinformatics analysis. Bioinformatics analysis was conducted using TargetScan (TargetScan Release 7.2; www. targetscan.org;) to identify the target gene of miR-129-5p. A predicted target site of miR-129-5p was identified in the BMP2 3'UTR region.

Luciferase reporter assay. The BMP2 3'UTR and BMP2 3'UTR mutants, which were synthesized by Shanghai GenePharma Co., Ltd., were constructed into pmirGLO Dual-Luciferase vector (Promega Corporation) and referred to as pGL-BMP2-3'UTR and pGL-mBMP2-3'UTR, respectively. HepG2 cells cultured in monolayers were digested using $0.25 \%$ trypsin, mixed into a single cell suspension with DMEM containing 10\% FBS and then seeded into 96-well culture plates at a density of 1,500-5,000 cells per well. When the cells grew to $60-70 \%$ confluence, were co-transfected with $100 \mathrm{ng}$ pGL-BMP2-3'UTR or $100 \mathrm{ng}$ pGL-mBMP2-3'UTR, miR-129-5p mimics $(50 \mathrm{nM})$ and $1 \mathrm{ng} \mathrm{pRL}-\mathrm{TK}$. The transfection reagent was Lipofectamine ${ }^{\circledR} 2000$ (Invitrogen; Thermo Fisher Scientific, Inc.) After 48 h, $200 \mu 1$ GLO-reagent (cat. no. E1960; Promega Corporation) was added to each well. Reaction at room temperature for $5 \mathrm{~min}$, the fluorescence intensity was measured by spectrophotometer.

MTT cell cytotoxicity assay. Cells cultured in monolayers were digested using $0.25 \%$ trypsin, mixed into a single cell suspension with DMEM containing 10\% FBS and then seeded into 96-well culture plates at a density of 1,500-5,000 cells per well. After transfection with miR-129-5p mimics, cells were cultured at $37^{\circ} \mathrm{C}$ with $5 \% \mathrm{CO} 2$ and $95 \%$ relative humidity for 24,48 and $72 \mathrm{~h}$. Subsequently, cells were washed with PBS and suspended in serum-free medium. After adding $20 \mu 1$ MTT solution $(5 \mathrm{mg} / \mathrm{ml})$ into each well, the cells were incubated for $4 \mathrm{~h}$ at $37^{\circ} \mathrm{C}$. The culture supernatant was carefully removed from the well, $150 \mu 1$ DMSO was added into each well and the plate was shaken for $10 \mathrm{~min}$. The absorbance values at $490 \mathrm{~nm}$ were measured with an enzyme-linked immunosorbent assay. Cell proliferation was depicted with time as the horizontal axis and the absorbance value as the vertical axis.
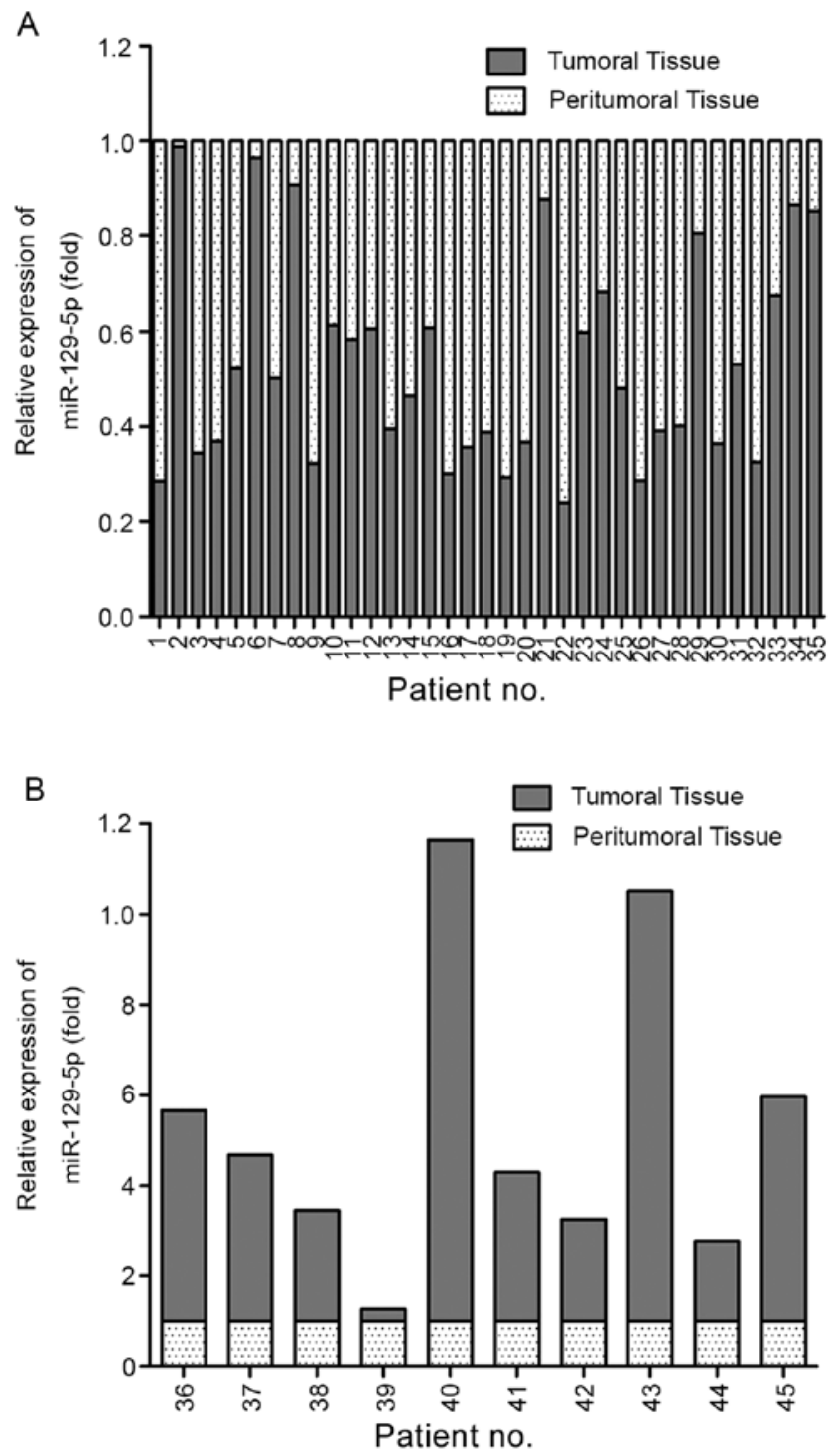

Figure 1. Expression of miR-129-5p in tumoral and peritumoral tissue of patients with hepatocellular carcinomas. (A) Tumoral tissues presenting lower levels of miR-129-5p than the peritumoral tissue. (B) Tumoral tissues presenting higher levels of miR-129-5p than the peritumoral tissue. Expression of miR-129-5p was normalized to U6 snRNA. miR-129-5p was downregulated in $77.78 \%$ of tumoral tissues $(n=35)$ compared with the matched peritumoral tissues. Different degrees of upregulation were observed in the remaining ten cases. miR, microRNA.

Invasion and migration assay. Invasion and migration of HepG2 or Huh7 cells were detected using Transwell invasion assay and wound healing assay, respectively. Migration of HepG2 and Huh7 cells was detected using a scratch wound assay. Briefly, at $48 \mathrm{~h}$ after transfection, HepG2 or Huh7 cells, which were transfected with NC mimics, miR-129-5p mimics, NC inhibitor or miR-129-5p inhibitor, were grown on $6-\mathrm{cm}$ dishes and to a density of $70-80 \%$. The cell monolayer was then scraped using a sterile cell scraper to create a cell-free zone. The cells were cultured with serum-free DMEM medium. HepG2 or Huh7 cell migration was photographed at the time of injury and after $48 \mathrm{~h}$ of cultivation, using an inverted light microscope, at five distinct positions per dish and x200 magnification.

In the invasion assay, after cell transfection in serum-free culture, $2 \times 10^{4}$ cells were seeded into the upper chamber of 

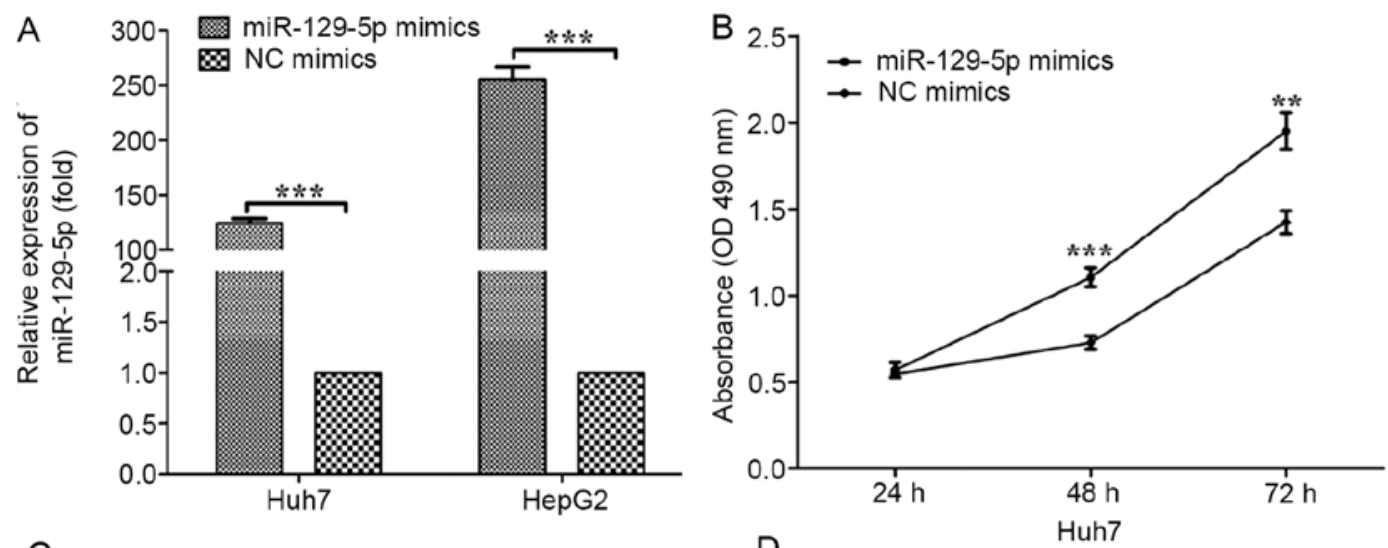

C
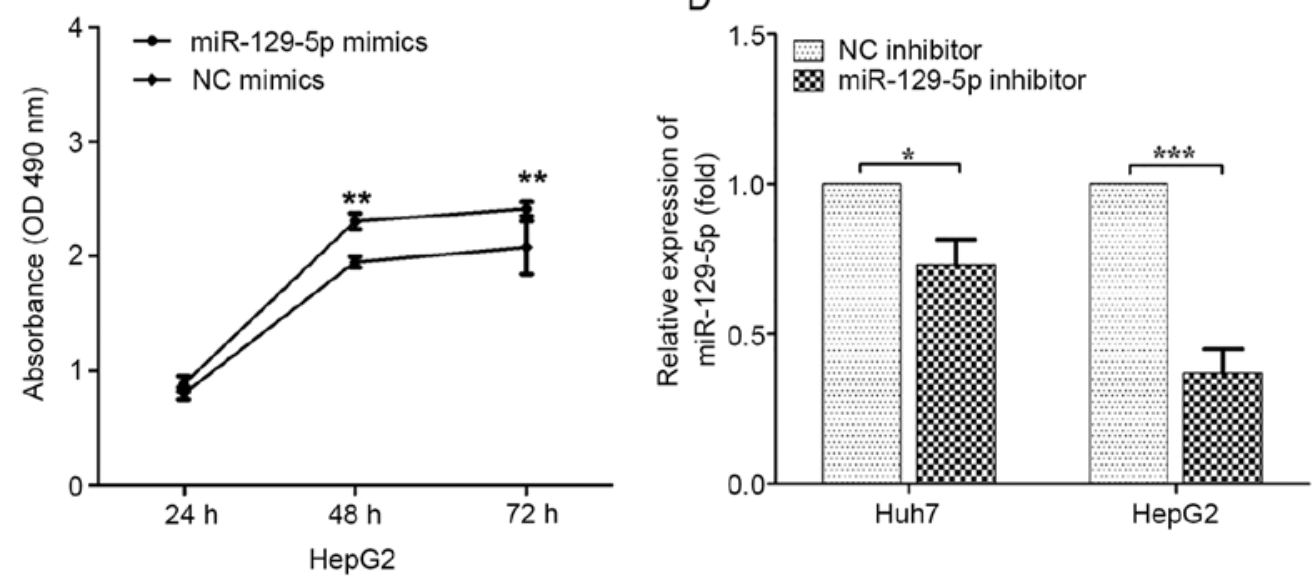

E
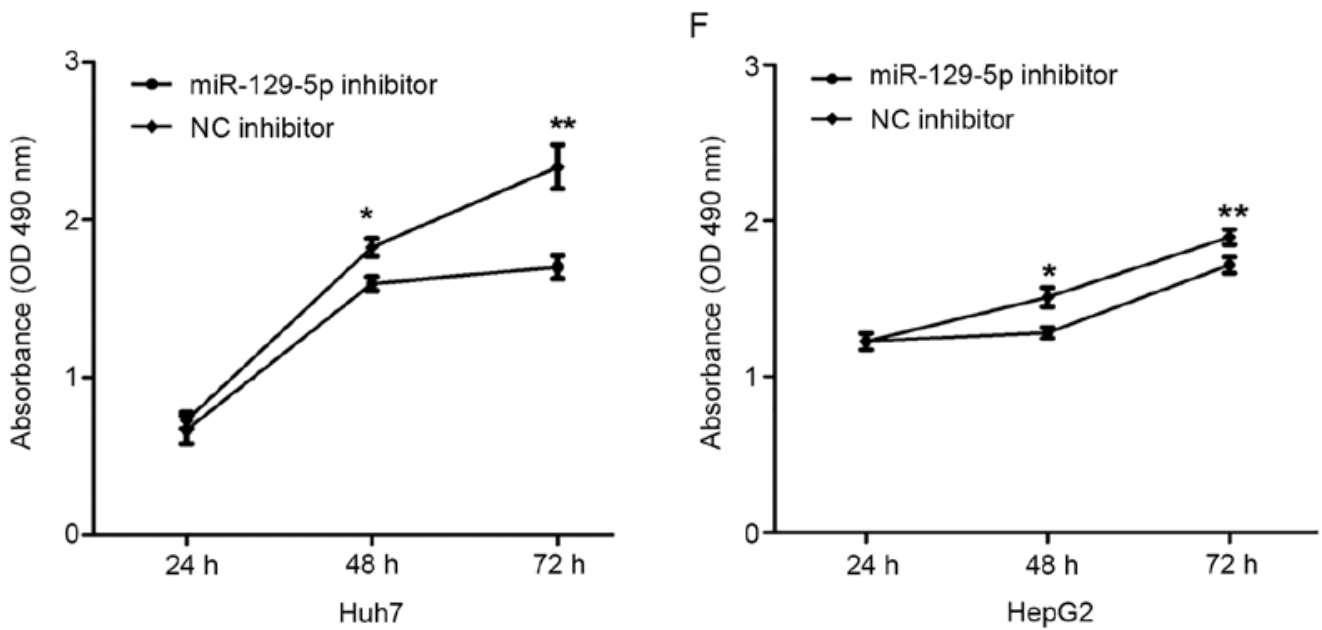

Figure 2. miR-129-5p regulates cell proliferation. (A) Relative expression of miR-129-5p in Huh7 and HepG2 cells after transfection with miR-129-5p mimics or NC mimics. ${ }^{* * *} \mathrm{P}<0.001$. MTT assays were performed in (B) Huh7 and (C) HepG2 cells after transfection of miR-129-5p mimics or NC mimics. ${ }^{* *} \mathrm{P}<0.01$ and ${ }^{* * *} \mathrm{P}<0.001$ vs. NC mimics. (D) Relative expression of miR-129-5p in Huh7 and HepG2 cells after transfection with miR-129-5p inhibitor or NC inhibitor ${ }^{*} \mathrm{P}<0.05$ and ${ }^{* * *} \mathrm{P}<0.001$ vs. NC inhibitor. MTT assays were performed in (E) Huh7 and (F) HepG2 cells after transfection of miR-129-5p inhibitor or NC inhibitor. ${ }^{*} \mathrm{P}<0.05$ and ${ }^{* *} \mathrm{P}<0.01$. Data are presented as the mean $\pm \mathrm{SD}$ from $\geq 3$ independent experiments. miR, microRNA; NC, negative control; OD, optical density.

a 24-well Transwell unit with $8-\mu \mathrm{m}$ polycarbonate nucleopore filters (Corning, Inc.) and a $40 \mu \mathrm{l}(1 \mathrm{mg} / \mathrm{ml})$ Matrix gel (Sigma-Aldrich; Merck KGaA), which was added prior to plating. Before seeding the cells, the filters of the Transwell unit were coated with the Matrix gel at $37^{\circ} \mathrm{C}$ for $4 \mathrm{~h}$ to form a reconstructed basement membrane. The upper compartment contained serum-free DMEM medium whilst the lower compartment contained DMEM medium with 5\% FBS. The cells were incubated for $30 \mathrm{~h}$ in a humidified atmosphere of
$5 \% \mathrm{CO}_{2}$ at $37^{\circ} \mathrm{C}$. The cells adhering to the lower surface of the filter were stained with the $1 \%$ crystal violet solution in $70 \%$ ethanol, at room temperature for $30 \mathrm{~min}$ and were counted. The cells were calculated with an inverted light microscope from $\geq$ five representative fields and x200 magnification.

Statistical analysis. Statistical analysis was performed using SPSS software version 18.0 (IBM Corp). Data are presented as the mean \pm SD. Each test was repeated $\geq 3$ times 
A
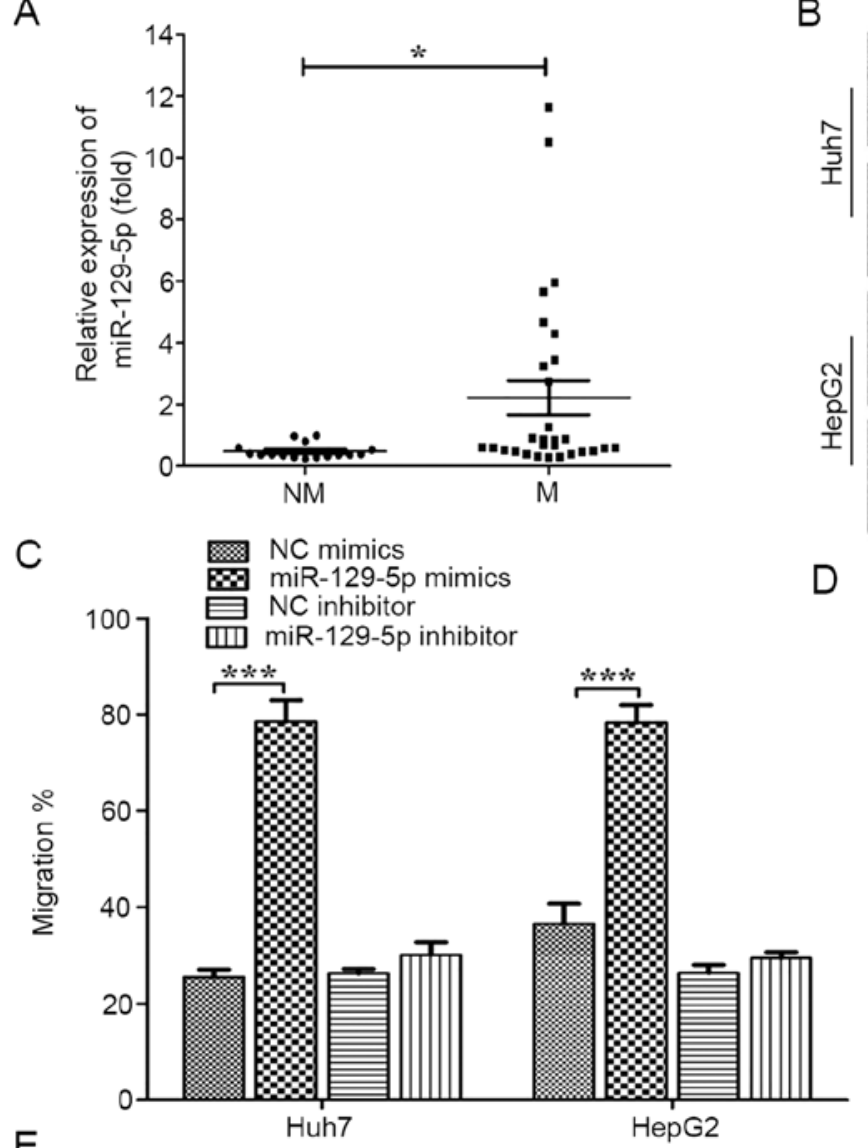

$\mathrm{E}$

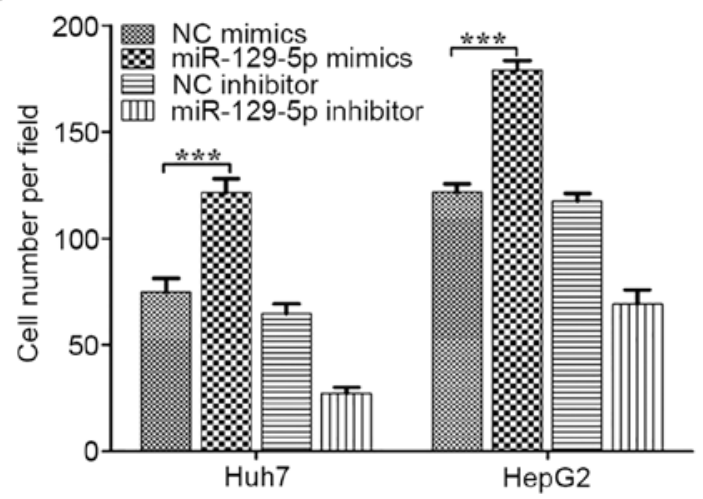

B
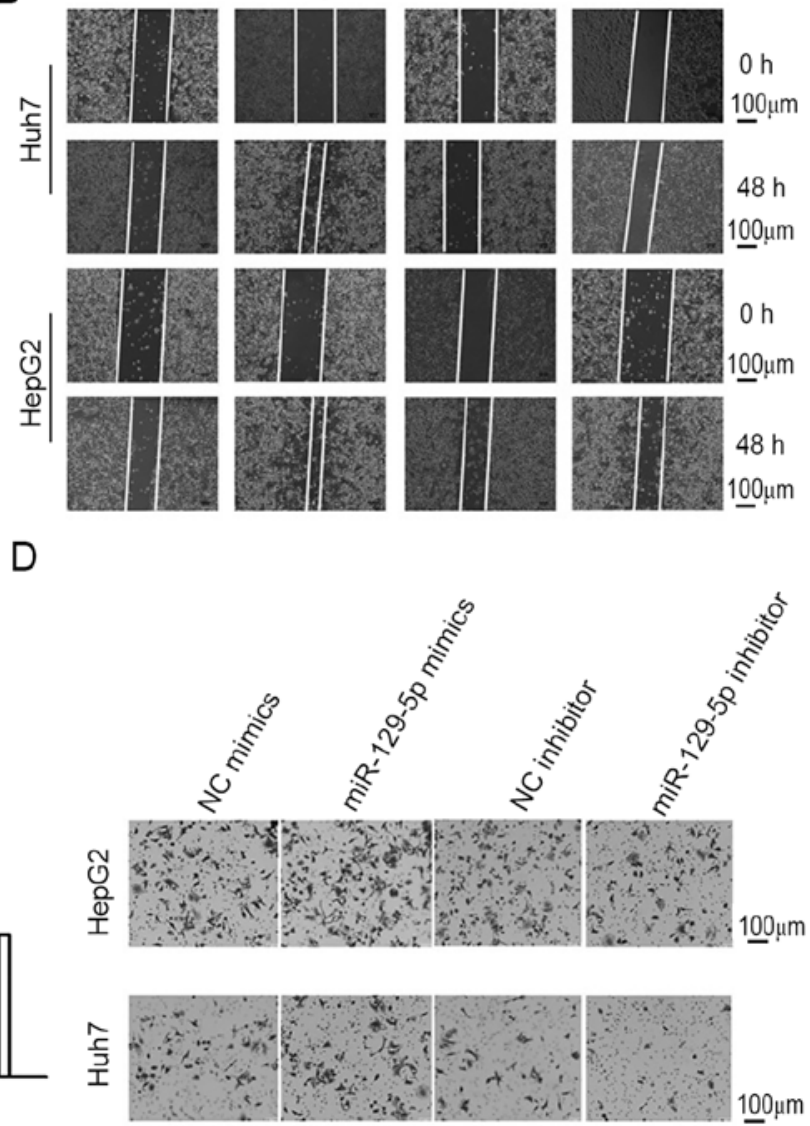

Figure 3. Role of miR-129-5p on migration and invasion in vivo and in vitro. (A) Expression of miR-129-5p in the $\mathrm{M}$ group ( $\mathrm{n}=29)$ and the NM group ( $\mathrm{n}=16$ ) HCC specimens. "P<0.05. Wound healing or Transwell invasion assays were performed in HepG2 and Huh7 cells. (B) Migration of Huh7 and HepG2 cells. Magnification, $x 200$. (C) The extent of migration was increased after transfection with miR-129-5p mimics. ${ }^{* * * *} \mathrm{P}<0.001$. (D) Invasion assays of Huh7 and HepG2 cells. The invasive ability of the cells was enhanced after transfection with miR-129-5p mimics. (E) Number of invaded cells per filed were counted with the average count of 10 random fields. Magnification, $\mathrm{x} 200$. Data are presented as the mean $\pm \mathrm{SD}$ from $\geq 3$ independent experiments. ${ }^{* * * *} \mathrm{P}<0.001$. miR, microRNA; M, migration and invasion; NC, negative control; NM, non-migration and invasion.

independently. Student's paired and unpaired t-tests were used for comparisons between two groups. One-way ANOVA analysis using GraphPad Prism 7 (GraphPad Software, Inc.) with post hoc Tukey's multiple comparisons tests was used when comparing multiple groups. $\mathrm{P}<0.05$ was considered to indicate a statistically significant difference.

\section{Results}

Expression of miR-129-5p in HCC cell lines and tissue samples obtained from patients with liver cancer. The clinical characteristics of patients with liver cancer in this study are presented in Table I. The tumor size, intrahepatic metastases, vascular invasion and capsular invasion were used to analyze the proliferation, metastasis and invasion of tumors. To investigate the biological role of miR-129-5p in the development of human $\mathrm{HCC}$, the expression levels of miR-129-5p in 45 pairs of fresh liver tumoral tissues and cancerous peripheral tissue was analyzed using RT-qPCR. miR-129-5p was downregulated in $77.78 \%$ of tumoral tissues $(n=35)$ compared with the matched peritumoral tissues (Fig. 1A). Moreover, different degrees of upregulation were observed in the remaining ten cases (Fig. 1B). The results indicated that miR-129-5p is potentially involved in the development of human HCC. 
A

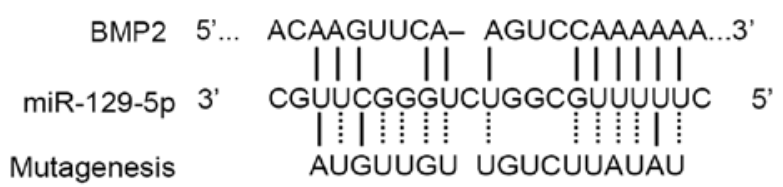

B

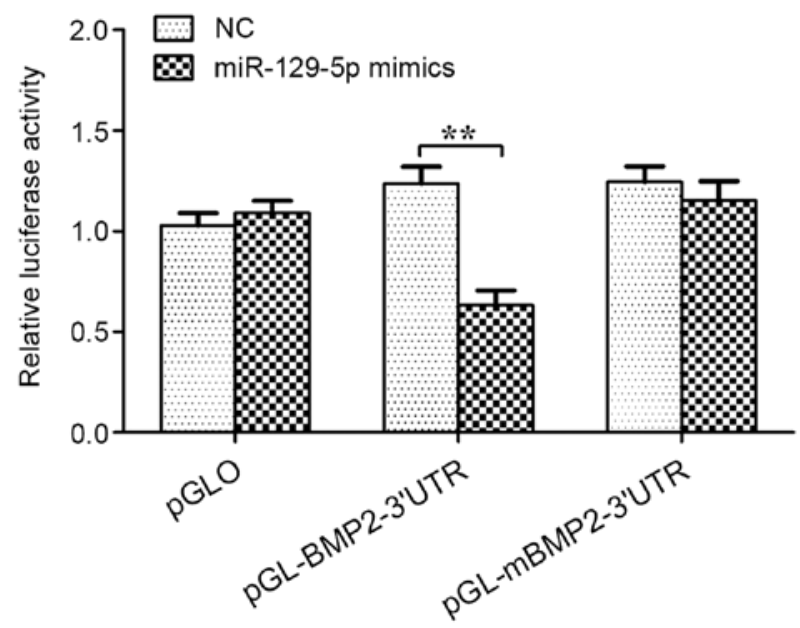

Figure 4. miR-129-5p directly targets the BMP2 3'UTR. (A) BMP2 3'UTR and BMP2 3'UTR mutant were constructed into pmirGLO Dual-Luciferase vector and designated as pGL-BMP2-3'UTR and pGL-mBMP2-3'UTR, respectively. HepG2 cells were co-transfected with pGL-BMP2-3'UTR, pGL-mBMP2-3'UTR, miR-129-5p mimics and pRL-TK. (B) Relative luciferase activities. After $48 \mathrm{~h}$ of transfection, luciferase activity was determined using a dual luciferase reporter assay system. Data are presented as the mean $\pm \mathrm{SD}$ from $\geq 3$ independent experiments. ${ }^{* *} \mathrm{P}<0.01$. miR, microRNA; UTR, untranslated region; BMP2, bone morphogenetic protein 2 .

Overexpression of $m i R-129-5 p$ promotes proliferation of HCC cells. To investigate the effect of miR-129-5p on the cytotoxicity of HCC cells, an MTT cytotoxicity assay was performed using HepG2 and Huh7 cells. The two types of liver cancer cells were divided into two groups and transfected with negative control (NC mimics) or miR-129-5p mimics and then measured for transfection efficiency. The expression of miR-129-5p in Huh7 and HepG2 cells was significantly higher than that in the NC mimics group (Fig. 2A). To investigate the effect of miR-129-5p on the cytotoxicity of HCC cells, MTT assay was performed with the same cells. The absorbance value of the cells in the miR-129-5p overexpression group was higher compared with that in the control group, indicating that the cytotoxicity rate was significantly lower compared with the control group in both cell lines (Fig. 2B and C). Therefore, miR-129-5p significantly reduced the cytotoxicity of HepG2 and Huh7 cells in vitro.

It was demonstrated that overexpression of miR-129-5p can reduce the cytotoxicity of $\mathrm{HCC}$, and thus, it was investigated whether this phenotype can be reversed by knockdown of miR-129-5p. To assess the role of miR-129-5p in HCC, cells were transfected with miR-129-5p inhibitor NC and miR-129-5p inhibitor, and a MTT assay was conducted after intracellular knockdown of miR-129-5p. Transfection with the miR-129-5p inhibitor was shown to significantly reduce the levels of miR-129-5p in both HepG2 or Huh7 cell lines (Fig. 2D). The number of viable cells in the miR-129-5p knockdown group was significantly lower compared with that in the control group, indicating that knockdown of miR-129-5p significantly promoted the cytotoxicity of both HCC cell lines (Fig. 2E and F).

miR-129-5p promotes migration and invasion of HCC cells. $\mathrm{HCC}$ is the second most deadly cancer type, with a strong invasive and metastatic capability being the primary reasons for the poor prognosis (2). Therefore, the present study focused on whether the reduction of miR-129-5p levels was related to the invasive and metastatic capabilities of liver cancer. The expression levels of miR-129-5p in tumor tissues of the patients $(n=45)$ with HCC in this study were compared between non-metastatic/invasive HCC samples $(n=16)$ and metastatic/invasive HCC samples, as well as those with intrahepatic metastasis, vascular invasion or capsule invasion $(n=29$; Fig. 3A). It was found that miR-129-5p was significantly downregulated in metastatic/invasive HCC samples.

To evaluate the effect of miR-129-5p on the migration and invasion of liver cancer, wound healing and Transwell assays were conducted using HepG2 and Huh7 cells. The results of the migration assays suggested that the migratory capacity $48 \mathrm{~h}$ after scratch in the miR-129-5p overexpression group was significantly greater compared with that of the control group, indicating the migration of cancer cells was significantly enhanced (Fig. 3B and C). In the Transwell assay (Fig. 3D and E), the miR-129-5p mimics group had significantly enhanced cell invasive capabilities compared with the control group, whilst the migratory ability of the two cell lines in the miR-129-5p inhibitor group was decreased, but there was no statistical significance. These results indicated that miR-129-5p promoted the migratory ability of liver cancer cells. Collectively, the present results suggested that overexpression of miR-129-5p enhanced the migration and invasion of HCC cells and thus promoted the metastasis of HCC.

The interaction between miR-129-5p and BMP2 3'UTR region. In order to elucidate the mechanism of miR-129-5p action, bioinformatics analysis was conducted using www. targetscan.org to identify its target gene. A predicted target site for miR-129-5p was identified in the BMP2 3'UTR region. To investigate whether BMP2 was a direct target of miR-129-5p, luciferase reporter assays were performed in HepG2 cells. The results indicated that miR-129-5p significantly reduced the relative luciferase activity of BMP2 3'UTR ( 36\%). However, the relative luciferase activity of the mutant BMP2 3'UTR was not inhibited by miR-129-5p. Therefore, the results demonstrated that BMP2 may be a direct target gene for miR-129-5p (Fig. 4).

miR-129-5p inhibits the expression of BMP2. miRNAs can regulate gene expression by degrading $\mathrm{mRNA}$ or by preventing translation without affecting mRNA stability (15). To identify the regulatory mechanism of action for miR-129-5p, BMP2 mRNA and protein expression levels were detected following the overexpression of miR-129-5p in HepG2 and Huh7 cells. The overexpression of miR-129-5p appeared to reduce BMP2 mRNA and protein expression levels in both cells (Fig. 5). Thus, miR-129-5p may have suppressed the expression levels of BMP2 at the post-transcriptional level by degrading its mRNA. 
A

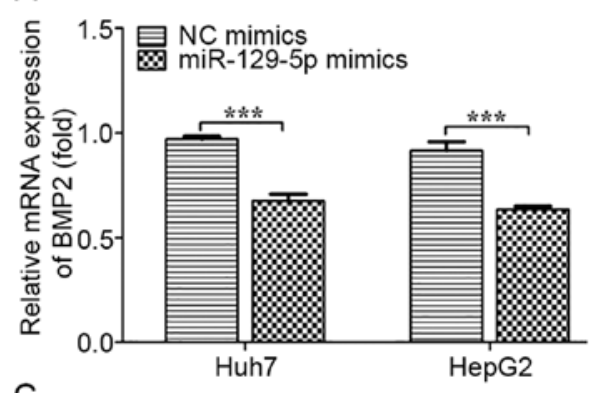

C

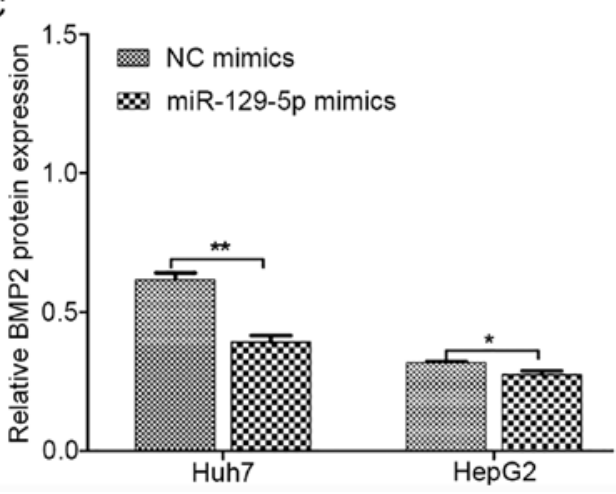

B

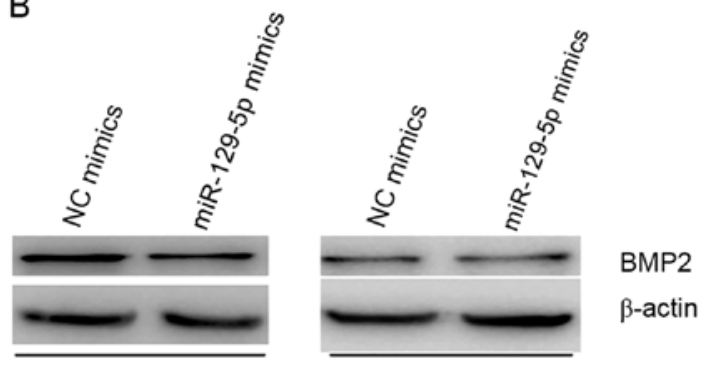

Huh7
HepG2

$\beta$-actin

Figure 5. mRNA and protein expression levels of BMP2 after transfection with miR-129-5p mimics in Huh7 and HepG2 cells. (A) Reverse transcription-quantitative PCR was performed to detect the mRNA expression levels of BMP2 after transfection with miR-129-5p mimics in Huh7 and HepG2 cells. (B) Western blotting was performed to detect the protein expression levels of BMP2 after transfection with miR-129-5p mimics in Huh7 and HepG2 cells. (C) Analysis of gray values of BMP2 protein expression. Data are presented as the mean \pm SD from $\geq 3$ independent experiments. ${ }^{*} \mathrm{P}<0.05,{ }^{* *} \mathrm{P}<0.01$ and ${ }^{* * * *} \mathrm{P}<0.001$. miR, microRNA; NC, negative control; BMP2, bone morphogenetic protein 2.

A

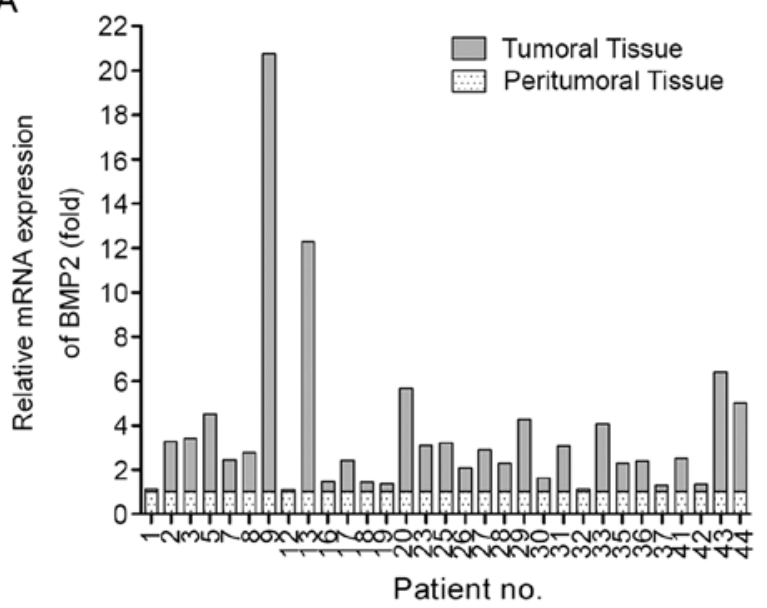

B

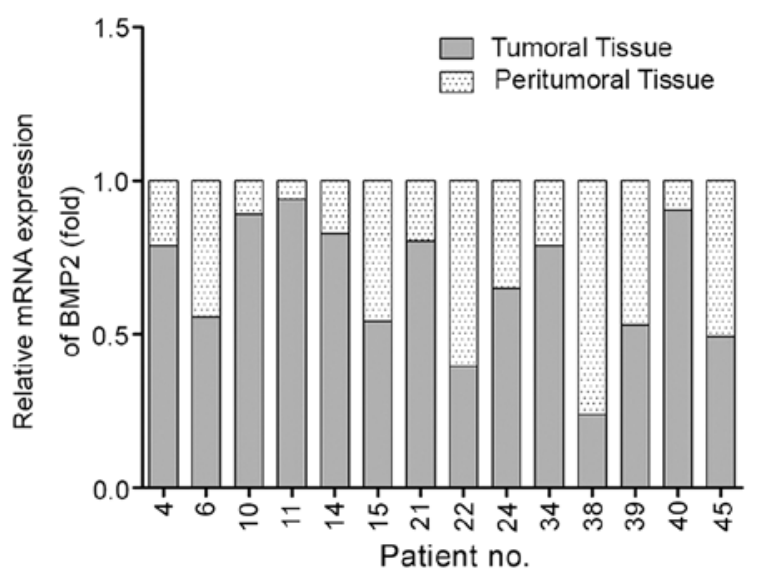

Figure 6. Expression of BMP2 mRNA in tumoral and peritumoral tissue from patients with hepatocellular carcinoma. (A) Tumoral tissues presenting lower levels of BMP2 than the peritumoral tissue. (B) Tumoral tissues presenting higher levels of BMP2 than the peritumoral tissue. Expression of BMP2 mRNA expression was normalized to $\beta$-actin. BMP2 was highly expressed in 31/45 cases of liver cancer tissues, which had different degrees of increase compared with the matched peritumoral tissue, while the expression levels of BMP2 were reduced to different degrees in the remaining 14 cases. BMP2, bone morphogenetic protein 2 .

Negative correlation between $m i R-129-5 p$ and $B M P 2$ expression levels in human HCC. The important role of BMP2 in tumor proliferation, invasion and metastasis has been reported in previous studies (39-44). To determine the clinical significance of BMP2, the mRNA expression level of BMP2 was examined in 45 pairs of liver tumoral tissues. BMP2 was highly expressed in 31/45 cases of liver tumoral tissues, which had different degrees of increase compared with the matched peritumoral tissue, while the expression of BMP2 was reduced to different degrees in the remaining 14 cases (Fig. 6A and B).

\section{Discussion}

HCC is one of the most aggressive tumor types worldwide (1-3). Due to the high rate of intrahepatic and extrahepatic metastasis, patients with $\mathrm{HCC}$ often have a poor prognosis and high recurrence possibility (45). Proliferation and metastasis are the 
most important characteristics of cancer and contribute to the high mortality of malignant tumors, especially HCC (46-48). Advancement in the research of miRNAs, as a regulatory basis behind $\mathrm{HCC}$, has provided novel insights into the development of HCC. It has been revealed that miRNAs, such as miR-320 and miR-107, play an important regulatory role in the proliferative and metastatic potential of $\operatorname{HCC}(49,50)$. miR-129-5p exhibits a regulatory effect on the onset and progression of various tumor types by regulating the cell cycle, proliferation, apoptosis, migration, invasion and angiogenesis, as well as other physiological and pathological processes (25). In neuroblastomas, miR-129 inhibits tumor growth by targeting MYO10 (35). Furthermore, miR-129-5p enhances cell proliferation and invasion; and inhibits apoptosis by regulating SOX4 in renal cell carcinoma (26). A previous study reported that miR-129-5p is a biomarker of single ventricular heart failure (36). miR-129 expression may be an independent prognostic marker for BCR-free survival in patients with prostate cancer and the overexpression of miR-129 significantly attenuates prostate cancer cell proliferation by regulating cell cycle-regulated protein expression levels (27). However, to the best of our knowledge, there are no reports on miR-129-5p and HCC, and thus, the aim of the present study was to investigate the effect of miR-129-5p on the proliferation and invasion of $\mathrm{HCC}$ cells.

In the present study, Huh7 was selected as a typical HCC cell line and HepG2 was chosen as another liver cancer cell line for the in vitro investigation into HCC. Although HepG2 has been shown to be a hepatoblastoma in recent years, $>9,000$ articles have used HepG2 as hepatocarcinoma or hepatoma from 1979 to March 2009. In 2019 (51), previous studies (52-55) have used HepG2 as a HCC cell line. The aim of the present study was to examine the effect of miR-129-5p on the proliferative and metastatic abilities of HCC. The exact properties of HepG2 cells was not the focus of this study and the use of HepG2 did not affect the purpose and the results of the present study $(51,56,57)$.

In the present study, it was found that 35/45 tumoral tissue samples had a decrease in miR-129-5p expression levels, suggesting that miR-129-5p was involved in the progression of liver cancer. Moreover, upregulation of miR-129-5p levels was identified in $22.22 \%$ of tumoral tissue samples. However, the mechanism of action responsible for the regulation of miR-129-5p in liver cancer requires further investigation. Previous studies have reported that miRNAs are involved in the regulation of signal transduction pathways in HCC tumorigenesis and metastasis $(49,50,58)$. In the current study, miR-129-5p was found to be involved in all stages of liver cancer and its involvement in the proliferation, invasion and migration of liver cancer was demonstrated. Furthermore, miR-129-5p was used to effectively distinguish 16 cases of non-metastatic/invasive HCC from 29 cases of metastatic/invasive HCC. Collectively, the present results suggested that miR-129-5p was involved in the invasion and metastasis of liver cancer.

BMP, a member of the TGF- $\beta$ superfamily, plays an important role in cell proliferation, differentiation, apoptosis and morphogenesis of various tissues and organs in the body $(59,60)$. BMP2 is expressed in several tumor types, such as osteosarcoma, pancreatic cancer and breast cancer, and has notable effects on cell proliferation and metastasis $(26,36)$.
Although the relationship between BMP2 and various tumors, as well as the relevant mechanism of action, has been previously reported $(26,36,59,60)$, the effects of BMP 2 on the development of HCC remains unknown. The present study identified the potential target gene of miR-129-5p as BMP2 through bioinformatics database analysis and found that miR-129-5p can bind to a target site on the BMP2 3'UTR, using luciferase reporter detection technology. In addition, BMP2 was demonstrated to be the target gene of miR-129-5p by detecting the mRNA and protein expression levels of BMP2 in cells after transfection with miR-129-5p mimics. BMP2 expression was post-transcriptionally regulated by miR-129-5p. Furthermore, miR-129-5p expression levels were found to be negatively correlated with BMP2 expression levels in liver tumoral tissue samples. It was also found that BMP2 was highly expressed in 31/45 cases of liver tumoral tissues, which had different degrees of increased expression compared with the matched para-carcinoma tissue, while 14 cases had different degrees of reduced expression levels. The last new finding of the present study is that miR-129-5p may facilitate HCC pathogenesis through the BMP2. The newly identified miR-129-5p/BMP2 axis provides new insight into the pathogenesis of HCC. In conclusion, the present results demonstrated that miR-129-5p may promote the proliferation, migration and invasion of HCC cells, and play an important role in the cellular processes behind the development of HCC, by targeting BMP2.

\section{Acknowledgements}

Not applicable.

\section{Funding}

The present study was supported by the fund from the Department of Intervention, The First Affiliated Hospital of Harbin Medical University (Harbin, Heilongjiang, China).

\section{Availability of data and materials}

The datasets used and/or analyzed during the current study are available from the corresponding author on reasonable request.

\section{Authors' contributions}

ZL designed the study, performed the experiments and wrote the manuscript. ZL and JS performed the experiments and organized the images. XW and JS participated in this experiment and made substantial contributions to the acquisition of data. ZL analyzed and interpreted the data and organized the image. ZL and ZC can authenticate the raw data. XW and $\mathrm{ZC}$ helped write the manuscript, and were responsible for the study funding and in the conception and design of the study, as well as providing final approval of the version to be published. All authors have read and approved the final manuscript.

\section{Ethics approval and consent to participate}

The present study was approved by the Institutional Ethics Committee of Harbin Medical University (Harbin, China). Written informed consent was obtained from all patients. 


\section{Patient consent for publication}

Not applicable.

\section{Competing interests}

The authors declare that they have no competing interests.

\section{References}

1. Nakayama $\mathrm{H}$ and Takayama T: Role of surgical resection for hepatocellular carcinoma based on Japanese clinical guidelines for hepatocellular carcinoma. World J Hepatol 7: 261-269, 2015.

2. Torre LA, Bray F, Siegel RL, Ferlay J, Lortet-Tieulent J and Jemal A: Global cancer statistics, 2012. CA Cancer J Clin 65 87-108, 2015

3. Braillon A: Hepatocellular carcinoma. Lancet 380: 469-471, 2012.

4. Knudson AG Jr: Mutation and cancer: Statistical study of retinoblastoma. Proc Natl Acad Sci USA 68: 820-823, 1971.

5. He X, Yan YL, Eberhart JK, Herpin A, Wagner TU, Schartl M and Postlethwait JH: miR-196 regulates axial patterning and pectoral appendage initiation. Dev Biol 357: 463-477, 2011.

6. Poy MN, Hausser J, Trajkovski M, Braun M, Collins S, Rorsman P, Zavolan M and Stoffel M: miR-375 maintains normal pancreatic alpha- and beta-cell mass. Proc Natl Acad Sci USA 106: 5813-5818, 2009.

7. Ahn SM, Jang SJ, Shim JH, Kim D, Hong SM, Sung CO, Baek D, Haq F, Ansari AA, Lee SY, et al: Genomic portrait of resectable hepatocellular carcinomas: Implications of RB1 and FGF19 aberrations for patient stratification. Hepatology 60: 1972-1982, 2014.

8. Takai A, Dang HT and Wang XW: Identification of drivers from cancer genome diversity in hepatocellular carcinoma. Int J Mol Sci 15: 11142-11160, 2014.

9. Hu TH, Huang CC, Lin PR, Chang HW, Ger LP, Lin YW, Changchien CS, Lee CM and Tai MH: Expression and prognostic role of tumor suppressor gene PTEN/MMAC1/TEP1 in hepatocellular carcinoma. Cancer 97: 1929-1940, 2003.

10. Kawamura N, Nagai H, Bando K, Koyama M, Matsumoto S, Tajiri T, Onda M, Fujimoto J, Ueki T, Konishi N, et al: PTEN/MMAC1 mutations in hepatocellular carcinomas: Somatic inactivation of both alleles in tumors. Jpn J Cancer Res 90: 413-418, 1999.

11. Hellebrekers DM, Griffioen AW and van Engeland M: Dual targeting of epigenetic therapy in cancer. Biochim Biophys Acta 1775: 76-91, 2007.

12. Nault JC and Villanueva A: Intratumor molecular and phenotypic diversity in hepatocellular carcinoma. Clin Cancer Res 21: 1786-1788, 2015.

13. Nault JC, Mallet M, Pilati C, Calderaro J, Bioulac-Sage P, Laurent C, Laurent A, Cherqui D, Balabaud C and Zucman-Rossi J: High frequency of telomerase reverse-transcriptase promoter somatic mutations in hepatocellular carcinoma and preneoplastic lesions. Nat Commun 4: 2218, 2013.

14. Vishnoi A and Rani S: MiRNA biogenesis and regulation of diseases: An overview. Methods Mol Biol 1509: 1-10, 2017.

15. Lee RC, Feinbaum RL and Ambros V: The C. elegans heterochronic gene lin-4 encodes small RNAs with antisense complementarity to lin-14. Cell 75: 843-854, 1993

16. van Rooij E and Olson EN: MicroRNAs: Powerful new regulators of heart disease and provocative therapeutic targets. J Clin Invest 117: 2369-2376, 2007

17. Johnston RJ Jr, Chang S, Etchberger JF, Ortiz CO and Hobert O MicroRNAs acting in a double-negative feedback loop to control a neuronal cell fate decision. Proc Natl Acad Sci USA 102 $12449-12454,2005$.

18. Kloosterman WP, Wienholds E, de Bruijn E, Kauppinen S and Plasterk RH: In situ detection of miRNAs in animal embryos using LNA-modified oligonucleotide probes. Nat Methods 3 : 27-29, 2006

19. Chen CZ, Li L, Lodish HF and Bartel DP: MicroRNAs modulate hematopoietic lineage differentiation. Science 303: 83-86, 2004.

20. Appolloni R, Formicola R, Scurci M, Appolloni R and Colonna GB: Lupus anticoagulant and bilateral optic disc edema: A case report. Ann Ophthalmol 23: 312-317, 1991.
21. Calin GA, Sevignani C, Dumitru CD, Hyslop T, Noch E, Yendamuri S, Shimizu M, Rattan S, Bullrich F, Negrini M and Croce CM: Human microRNA genes are frequently located at fragile sites and genomic regions involved in cancers. Proc Natl Acad Sci USA 101: 2999-3004, 2004.

22. Esquela-Kerscher A and Slack FJ: Oncomirs-microRNAs with a role in cancer. Nat Rev Cancer 6: 259-269, 2006.

23. Chen CZ: MicroRNAs as oncogenes and tumor suppressors. N Engl J Med 353: 1768-1771, 2005.

24. Hammond SM: MicroRNAs as tumor suppressors. Nat Genet 39 582-583, 2007.

25. Finnerty JR, Wang WX, Hébert SS, Wilfred BR, Mao G and Nelson PT: The miR-15/107 group of microRNA genes: Evolutionary biology, cellular functions, and roles in human diseases. J Mol Biol 402: 491-509, 2010.

26. Liu Q, Li Y, Lv W, Zhang G, Tian X, Li X, Cheng H and Zhu C: UCA1 promotes cell proliferation and invasion and inhibits apoptosis through regulation of the miR129-SOX4 pathway in renal cell carcinoma. Onco Targets Ther 11: 2475-2487, 2018

27. Xu S, Yi XM, Zhang ZY, Ge JP and Zhou WQ: miR-129 predicts prognosis and inhibits cell growth in human prostate carcinoma. Mol Med Rep 14: 5025-5032, 2016.

28. Fu S, Fei Q, Jiang H, Chuai S, Shi S, Xiong W, Jiang L, Lu C, Atadja P, Li E and Shou J: Involvement of histone acetylation of Sox 17 and Foxa2 promoters during mouse definitive endoderm differentiation revealed by microRNA profiling. PLoS One 6: e27965, 2011.

29. Xu H, He JH, Xiao ZD, Zhang QQ, Chen YQ, Zhou H and Qu LH: Liver-enriched transcription factors regulate microRNA-122 that targets CUTL1 during liver development. Hepatology 52: 1431-1442, 2010

30. Huang $\mathrm{S}$ and He $\mathrm{X}$ : The role of microRNAs in liver cancer progression. Br J Cancer 104: 235-240, 2011.

31. Zhang Y, Yang P and Wang XF: Microenvironmental regulation of cancer metastasis by miRNAs. Trends Cell Biol 24: 153-160, 2014

32. Chai ZT, Kong J, Zhu XD, Zhang YY, Lu L, Zhou JM, Wang LR, Zhang KZ, Zhang QB, Ao JY, et al: MicroRNA-26a inhibits angiogenesis by down-regulating VEGFA through the PIK3C2 $\alpha / \mathrm{Akt} / \mathrm{HIF}-1 \alpha$ pathway in hepatocellular carcinoma. PLoS One 8: e77957, 2013.

33. Laudadio I, Manfroid I, Achouri Y, Schmidt D, Wilson MD, Cordi S, Thorrez L, Knoops L, Jacquemin P, Schuit F, et al: A feedback loop between the liver-enriched transcription factor network and miR-122 controls hepatocyte differentiation. Gastroenterology 142: 119-129, 2012.

34. Yang H, Cho ME, Li TW, Peng H, Ko KS, Mato JM and Lu SC: MicroRNAs regulate methionine adenosyltransferase 1A expression in hepatocellular carcinoma. J Clin Invest 123: 285-298, 2013.

35. Wang X, Li J, Xu X, Zheng J and Li Q: miR-129 inhibits tumor growth and potentiates chemosensitivity of neuroblastoma by targeting MYO10. Biomed Pharmacother 103: 1312-1318, 2018.

36. Ramachandran S, Lowenthal A, Ritner C, Lowenthal S and Bernstein HS: Plasma microvesicle analysis identifies microRNA 129-5p as a biomarker of heart failure in univentricular heart disease. PLoS One 12: e0183624, 2017.

37. Lv G, Hu Z, Tie Y, Du J, Fu H, Gao X and Zheng X: MicroRNA-451 regulates activating transcription factor 2 expression and inhibits liver cancer cell migration. Oncol Rep 32: 1021-1028, 2014.

38. Livak KJ and Schmittgen TD: Analysis of relative gene expression data using real-time quantitative PCR and the 2(-Delta Delta $\mathrm{C}(\mathrm{T}))$ method. Methods 25: 402-408, 2011.

39. Carragee EJ, Hurwitz EL and Weiner BK: A critical review of recombinant human bone morphogenetic protein-2 trials in spinal surgery: Emerging safety concerns and lessons learned. Spine J 11: 471-491, 2011 .

40. Jiramongkolchai P, Owens P and Hong CC: Emerging roles of the bone morphogenetic protein pathway in cancer: Potential therapeutic target for kinase inhibition. Biochem Soc Trans 44: $1117-1134,2016$.

41. Sampath TK, Coughlin JE, Whetstone RM, Banach D, Corbett C, Ridge RJ, Ozkaynak E, Oppermann H and Rueger DC: Bovine osteogenic protein is composed of dimers of OP-1 and BMP-2A, two members of the transforming growth factor-beta superfamily. J Biol Chem 265: 13198-13205, 1990.

42. Katsuno Y, Hanyu A, Kanda H, Ishikawa Y, Akiyama F, Iwase T, Ogata E, Ehata S, Miyazono K and Imamura T: Bone morphogenetic protein signaling enhances invasion and bone metastasis of breast cancer cells through Smad pathway. Oncogene 27: 6322-6333, 2008. 
43. Arnold SF, Tims E and Mcgrath BE: Identification of bone morphogenetic proteins and their receptors in human breast cancer cell lines: Importance of BMP2. Cytokine 11: 1031-1037, 1999.

44. Davies SR, Watkins G, Douglas-Jones A, Mansel RE and Jiang WG: Bone morphogenetic proteins 1 to 7 in human breast cancer, expression pattern and clinical/prognostic relevance. J Exp Ther Oncol 7: 327-338, 2008.

45. Budhu A, Forgues M, Ye QH, Jia HL, He P, Zanetti KA Kammula US, Chen Y, Qin LX, Tang ZY and Wang XW: Prediction of venous metastases, recurrence, and prognosis in hepatocellular carcinoma based on a unique immune response signature of the liver microenvironment. Cancer Cell 10: 99-111, 2006.

46. Aravalli RN, Cressman EN and Steer CJ: Cellular and molecular mechanisms of hepatocellular carcinoma: An update. Arch Toxicol 87: 227-247, 2013.

47. van Zijl F, Zulehner G, Petz M, Schneller D, Kornauth C, Hau M, Machat G, Grubinger M, Huber H and Mikulits W: Epithelial-mesenchymal transition in hepatocellular carcinoma. Future Oncol 5: 1169-1179, 2009.

48. Belghiti J and Fuks D: Liver resection and transplantation in hepatocellular carcinoma. Liver Cancer 1: 71-82, 2012.

49. Zou CD, Zhao WM, Wang XN, Li Q, Huang H, Cheng WP, Jin JF, Zhang H, Wu MJ, Tai S, et al: MicroRNA-107: A novel promoter of tumor progression that targets the CPEB3/EGFR axis in human hepatocellular carcinoma. Oncotarget 7: 266-278, 2016

50. Lv G, Wu M, Wang M, Jiang X, Du J, Zhang K, Li D, Ma N, Peng Y, Wang L, et al: miR-320a regulates high mobility group box 1 expression and inhibits invasion and metastasis in hepatocellular carcinoma. Liver Int 37: 1354-1364, 2017.

51. López-Terrada D, Cheung SW, Finegold MJ and Knowles BB: Hep G2 is a hepatoblastoma-derived cell line. Hum Pathol 40: $1512-1515,2009$.

52. Ahmed NM, Youns M, Soltan MK and Said AM: Design, synthesis, molecular modelling, and biological evaluation of novel substituted pyrimidine derivatives as potential anticancer agents for hepatocellular carcinoma. J Enzyme Inhib Med Chem 34: 1110-1120, 2019.
53. Su CM, Hou GG, Wang CH, Zhang HQ, Yang C, Liu M and Hou Y: Potential multifunctional agents with anti-hepatoma and anti-inflammation properties by inhibiting NF- $\kappa \mathrm{B}$ activation. J Enzyme Inhib Med Chem 34: 1287-1297, 2019.

54. Zhao J, Wang Y, Han M, Lu H, Chen X, Liu S, Yuan X, Han K, Liang P and Cheng J: P7TP3 inhibits tumor development, migration, invasion and adhesion of liver cancer through the Wnt/ $\beta$-catenin signaling pathway. Cancer Sci 111: 994-1007, 2020.

55. Xia Y, Zhong J, Zhao M, Tang Y, Han N, Hua L, Xu T, Wang C and Zhu B: Galactose-modified selenium nanoparticles for targeted delivery of doxorubicin to hepatocellular carcinoma. Drug Deliv 26: 1-11, 2019.

56. Aden DP, Fogel A, Plotkin S, Damjanov I and Knowles BB: Controlled synthesis of HBsAg in a differentiated human liver carcinoma-derived cell line. Nature 282: 615-616, 1979.

57. Knowles BB, Howe CC and Aden DP: Human hepatocellular carcinoma cell lines secrete the major plasma proteins and hepatitis B surface antigen. Science 209: 497-499, 1980.

58. Vasuri F, Visani M, Acquaviva G, Brand T, Fiorentino M, Pession A, Tallini G, D'Errico A and de Biase D: Role of microRNAs in the main molecular pathways of hepatocellular carcinoma. World J Gastroenterol 24: 2647-2660, 2018.

59. Mukai T, Otsuka F, Otani H, Yamashita M, Takasugi K, Inagaki K, Yamamura M and Makino H: TNF-alpha inhibits BMP-induced osteoblast differentiation through activating SAPK/JNK signaling. Biochem Biophys Res Commun 356: 1004-1010, 2007.

60. Huang RL, Yuan Y, Tu J, Zou GM and Li Q: Opposing TNF- $\alpha /$ IL-1 $\beta$ - and BMP-2-activated MAPK signaling pathways converge on Runx 2 to regulate BMP-2-induced osteoblastic differentiation. Cell Death Dis 5: e1187, 2014. 